\title{
A correlation analysis of the pollutant emission from a self ignition engine
}

\begin{abstract}
This paper presents the results of studies on pollution emissions from self-ignition engines. The studies were conducted on a Citroen Berlingo delivery van on a chassis test bed applying the ECE R 83 test with start-up of a warm engine. Pollutant emission intensity was registered in a continuous manner. The registered runs of pollutant emission intensity were subjected to digital processing. A correlation analysis was conducted subsequently. The Pearson, Spearman, Kendall, and Kruskal theories were applied in the study. The analysis demonstrated a clear correlation between the examined runs. The probability of non-rejection of the hypothesis regarding the lack of correlation was equal to zero with an accuracy of at least six places beyond the decimal point. An exception was the correlation test between carbon monoxide and carbon dioxide emission intensity processes for which the probability of non-rejection of the hypothesis regarding the lack of correlation amounted to a maximum of approximately $5 \%$.
\end{abstract}

Key words: transportation, environmental protection, pollutant emission, internal combustion engines, correlation analysis

\section{Analiza korelacyjna emisji zanieczyszczeń z silnika o zapłonie samoczynnym}

\begin{abstract}
W pracy przedstawiono wyniki badań emisji zanieczyszczeń z silnika o zapłonie samoczynnym. Badania wykonano na samochodzie dostawczym Citroen Berlingo na hamowni podwoziowej w teście wedlug regulaminu nr 83 EKG (Europejskiej Komisji Gospodarczej Organizacji Narodów Zjednoczonych), z rozruchem rozgrzanego silnika. Rejestrowano w ciagty sposób natężenia emisji zanieczyszczeń. Zarejestrowane przebiegi natężeń emisji zanieczyszczeń poddano przetwarzaniu cyfrowemu, a następnie przeprowadzono ich analize korelacyjna. Do badań wykorzystano teorie Pearsona, Spearmana, Kendalla i Kruskala. Analiza wykazała wyraźna korelację między badanymi przebiegami. Prawdopodobieństwo nieodrzucenia hipotezy o braku korelacji było równe zeru z dokładnościa co najmniej do sześciu znaków po przecinku; wyjątkiem byty badania korelacyjne między przebiegami natężeń emisji tlenku węgla i dwutlenku, dla których prawdopodobieństwo nieodrzucenia hipotezy o braku korelacji byto maksymalnie równe około 5\%.
\end{abstract}

Słowa kluczowe: transport, ochrona środowiska, emisja zanieczyszczeń, silniki spalinowe, analiza korelacyjna

\section{Introduction}

In addition to road traffic safety, questions relating to the environment have become the major issue of motoring over the past thirty to forty years. Following initial work on pollution emissions from combustion engines, primarily subject to static conditions as well as average evaluations subject to dynamic test conditions, increasingly great weight is being placed on classic dynamic tests $[1,2,4-6]$. Such tests include correlation analysis of dynamic processes $[6,8]$.

The acquisition of knowledge regarding the correlational interdependence of pollutant emission processes is important both in a cognitive sense and in practice. The practical aspect is tied with knowledge on the mutual influence of emission processes subject to dynamic conditions [2, 4-6, 8]. Knowledge to date mainly involves information related to static conditions, where at best such knowledge is verified through averaging under dynamic conditions. This is done in the case of the optimizing of algorithms for controlling the processes taking place inside combustion engines $[4$, 5], for example. Such algorithms are optimized for static conditions and correspond to states subject to dynamic conditions, where at best, such optimized algorithms are verified subject to dynamic conditions $[4,5]$.

This study involves the conducting of a correlational analysis [16] of pollutant emission processes from a self-

\section{Wprowadzenie}

Problematyka ekologiczna - obok spraw bezpieczeństwa ruchu drogowego - staje się w ciągu ostatnich 30-40 lat najważniejszą tematyką motoryzacji. Po początkowo prowadzonych pracach emisji zanieczyszczeń z silników spalinowych głównie w warunkach statycznych oraz uśrednionych ocen w warunkach testów dynamicznych coraz większą wagę przywiązuje się do klasycznych badań dynamicznych [1, 2, 4-6]. Do takich badań zalicza się m.in. analizę korelacyjną procesów dynamicznych $[6,8]$.

Zdobycie wiedzy na temat korelacyjnych zależności procesów emisji zanieczyszczeń ma znaczenie zarówno poznawcze, jak i praktyczne. Aspekt praktyczny jest związany z wiedzą o wpływie na siebie procesów emisji w warunkach dynamicznych $[2,4-6,8]$. Dotychczasowa wiedza dotyczy głównie takich informacji, odnoszących się do warunków statycznych, ewentualnie wiedza ta jest weryfikowana $\mathrm{w}$ formie uśredniania $\mathrm{w}$ warunkach dynamicznych. Tak się czyni m.in. w wypadku optymalizacji algorytmów sterowania procesów zachodzących w silnikach spalinowych $[4,5]$. Algorytmy te są optymalizowane w warunkach statycznych, odpowiadających stanom w warunkach dynamicznych, a następnie - w najlepszym razie - weryfikuje się tak zoptymalizowane algorytmy $\mathrm{w}$ warunkach dynamicznych $[4,5]$. 
ignition engine. The correlation analysis utilized the Pearson linear correlation theory [13], the Spearman rank order correlation theory [15], the Kendall tau coefficient correlation theory [9, 10], and the Kruskal Gamma theory [11].

\section{Research results}

Empirical tests were conducted on a chassis test bed on the Citroen Berlingo, a lightweight delivery van with a selfignition engine. Among the many types of tests available, including FTP 75 (Federal Test Procedure) [2], HWFET (Highway Fuel Economy Test) [2], and Stop and Go, all the way to congested traffic simulations [2] and Autobahn highway driving simulations [2], it was the ECE R 83 test that was selected, with start-up of a warm engine at temperatures for normal operating conditions.

The registered processes of pollutant emission intensity were digitally processed, eliminating gross errors and conducting low-pass filtration. The Golaya-Savitzky filter [14] with averaging parameters - dual-sided two point use and a seconddegree approximation polynomial - was applied for filtration.

Figures No. 1 and 2 present the chosen processes of the pollutant emission intensity - carbon monoxide, hydrocarbons, nitrogen oxides, and particulate matter. The particulate matter emissions intensity was established on the basis of measurements of the smoke coefficient, corrective methods for determining the concentrations of particulate matter [3], and the volume flow intensity of air. The smoke coefficient as well as the volume flow intensity of air were subjected to the same digital processing procedures as the processes of the pollutant emission intensity.
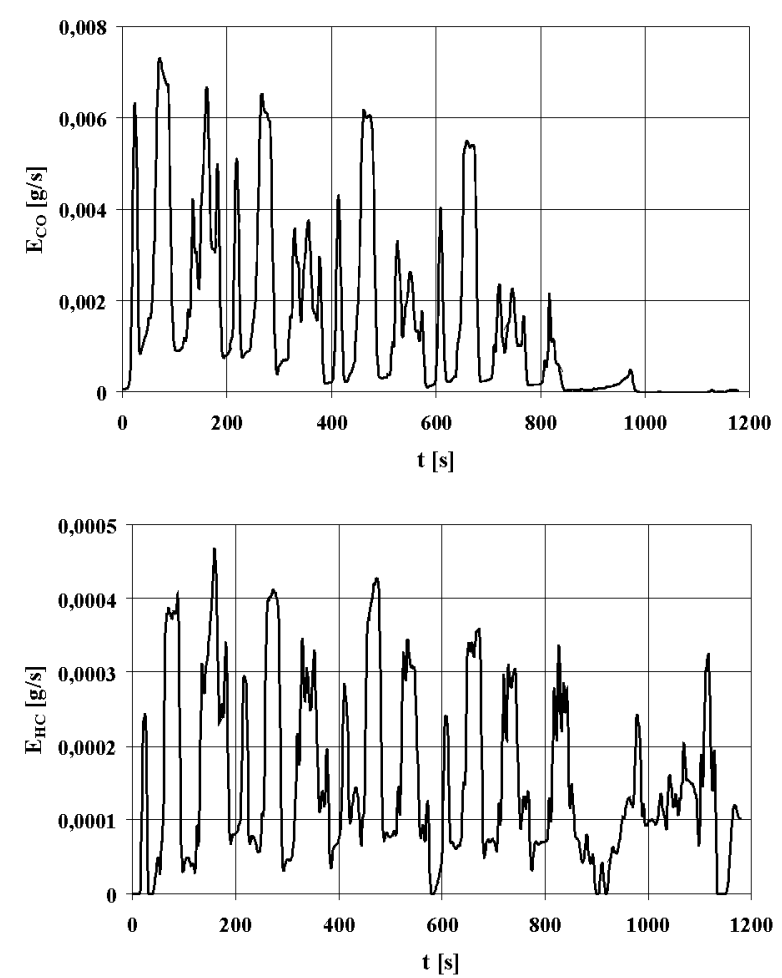

Fig. 1. The emission intensity of carbon monoxide $\mathrm{E}_{\mathrm{CO}}$ and hydrocarbons $\mathrm{E}_{\mathrm{HC}}$

Rys. 1. Natężenie emisji tlenku węgla $E_{C O}$ i węglowodorów $E_{H C}$
W niniejszej pracy przeprowadzono analizę korelacyjną [16] przebiegów emisji zanieczyszczeń z silnika o zapłonie samoczynnym. Do analizy korelacji wykorzystano teorię korelacji liniowej Pearsona [13] i teorię korelacji rang Spearmana [15], teorię korelacji tau Kendalla [9, 10] oraz teorię korelacji Gamma Kruskala [11].

\section{Wyniki badań}

Badania empiryczne przeprowadzono na lekkim samochodzie ciężarowym Citroën Berlingo z silnikiem o zapłonie samoczynnym na hamowni podwoziowej. Spośród wielu rodzajów testów, m.in. FTP 75 (Federal Test Procedure) [2], HWFET (Highway Fuel Economy Test) [2], Stop and Go do symulacji ruchu w warunkach kongestii [2] i Autobahn, symulujący ruch na autostradach [2], do analiz wybrano wyniki badań w teście wg regulaminu nr 83 EKG, przeprowadzanym z rozruchem silnika nagrzanego do warunków normalnej eksploatacji.

Zarejestrowane przebiegi natężeń emisji zanieczyszczeń przetworzono cyfrowo, eliminując duże błędy i przeprowadzając filtrację dolnoprzepustową. Do filtracji wykorzystano filtr Golaya-Savitzky'ego [14] z parametrami uśredniania: wykorzystanie obustronnie po dwa punkty oraz drugi stopień wielomianu aproksymującego.

Na rysunkach 1 i 2 przedstawiono przetworzone przykładowe przebiegi natężeń emisji zanieczyszczeń: tlenku węgla, węglowodorów, tlenków azotu i cząstek stałych. Natężenie emisji cząstek stałych wyznaczono na podstawie pomiarów współczynnika zadymienia spalin, korelacyjnych metod wyznaczania stężenia cząstek stałych [3] oraz zarejestrowanego
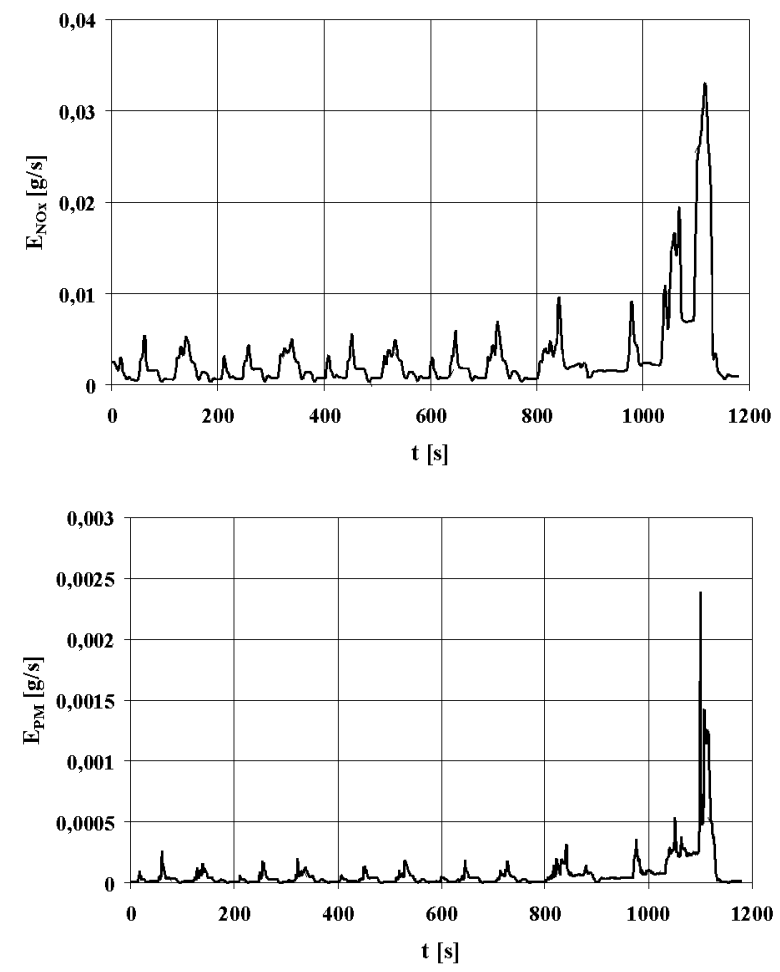

Fig. 2. The emission intensity of nitrogen oxides $\mathrm{E}_{\mathrm{NOx}}$ and particulate matter $\mathrm{E}_{\mathrm{PM}}$

Rys. 2. Natężenie emisji tlenków azotu $E_{N O x}$ i cząstek statych $E_{P M}$ 
Figures 3-9 present the chosen results of correlation analysis of the pollutant emission intensity - the correlation dependence for the pollutant emission intensity and the Pearson r, Spearman R, Kruskal Gamma, and Kendall tau correlation coefficients, as well as the probability of rejection of the hypothesis regarding an absence of correlations in the examined sets.
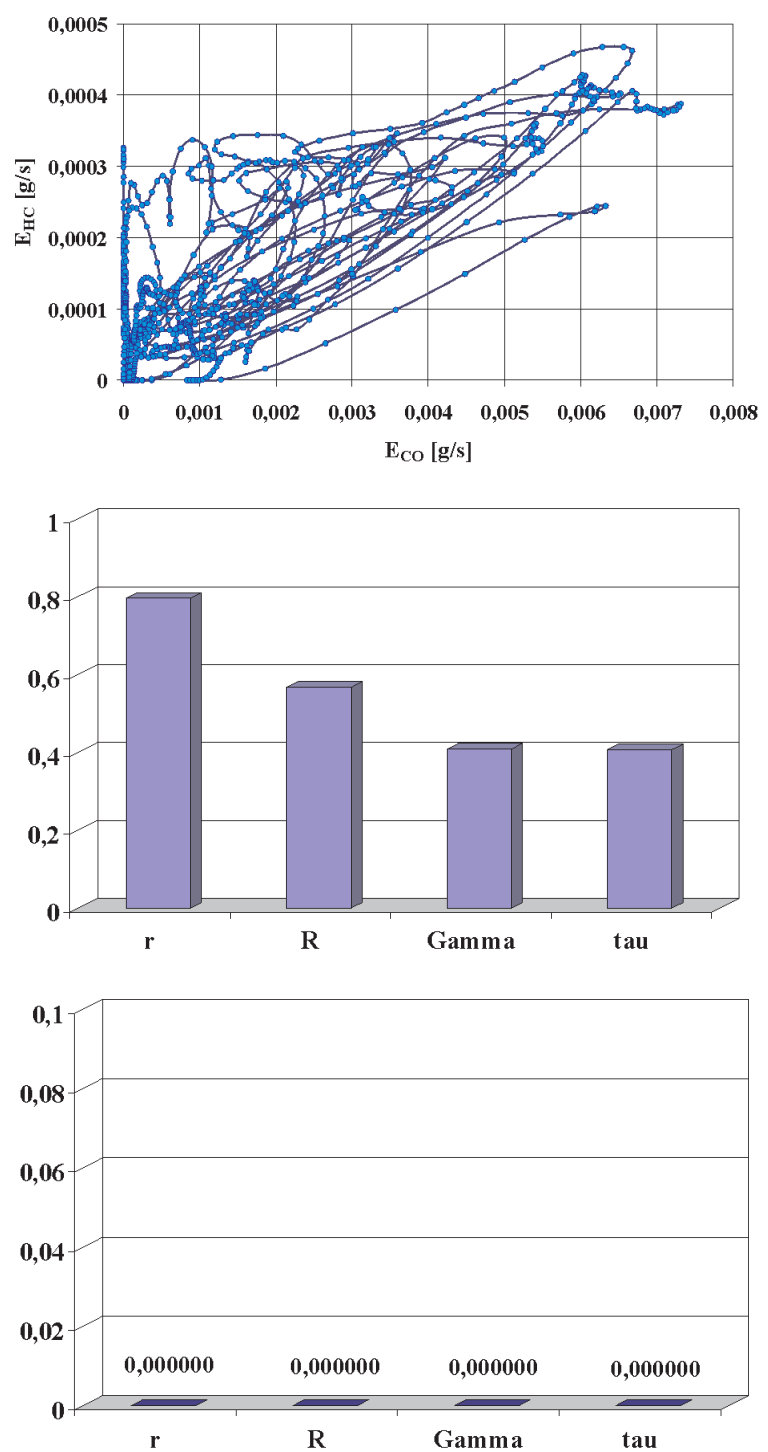

Fig. 3. Correlation dependence of the emission intensity of hydrocarbon $\mathrm{E}_{\mathrm{H}} \mathrm{C}$ and the emission intensity of carbon monoxide $\mathrm{E}_{\mathrm{CO}}$, the Pearson $\mathrm{r}$, Spearman R, Kruskal Gamma, and Kendall tau correlation coefficients, as well as the probability of rejection of the hypothesis regarding an absence of correlations in the examined sets

Rys. 3. Zależność korelacyjna natężenia emisji węglowodorów $E_{H C}$ i natężenia emisji tlenku węgla $E_{C O}$; wspótczynniki korelacji Pearsona r, Spearmana R, Kruskala Gamma i Kendalla tau oraz prawdopodobieństwo nieodrzucenia hipotezy o braku korelacji dla badanych zbiorów

The correlation of the emission rates of hydrocarbons and carbon monoxide is very strong. The probability of not rejecting of the hypothesis of a lack of correlation for the investigated sets is less than $5 \cdot 10^{-7}$. Such a strong correlation is physically and chemically substantiated by similar objętościowego natężenia przepływu powietrza zużywanego przez silnik. Przebiegi współczynnika zadymienia spalin oraz natężenia przepływu powietrza poddano takim samym procedurom przetwarzania cyfrowego jak przebiegi natężenia emisji zanieczyszczeń.

Na rysunkach 3-9 przedstawiono wybrane wyniki badań korelacyjnych natężeń emisji zanieczyszczeń: zależności
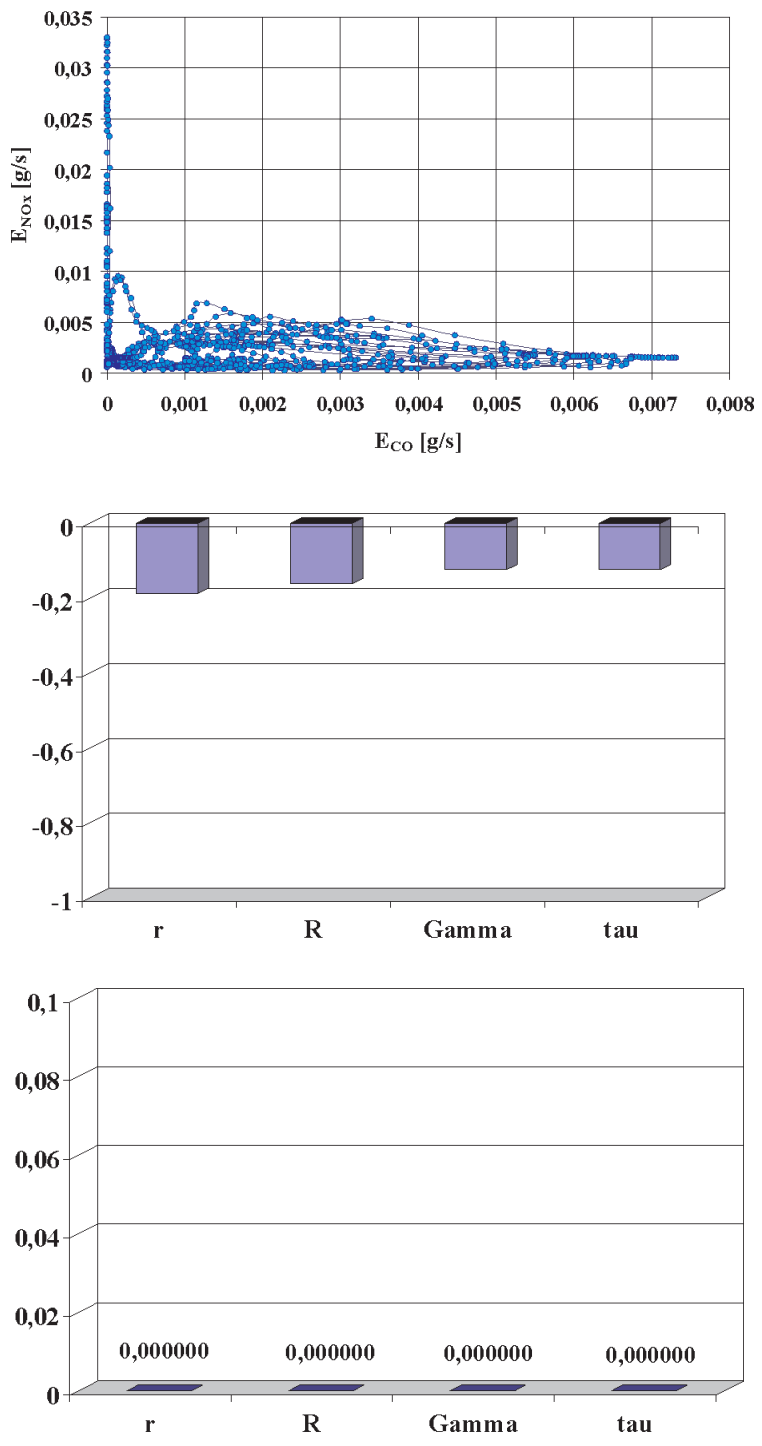

Fig. 4. Correlation dependence of the emission intensity of nitrogen oxides $\mathrm{E}_{\mathrm{NOx}}$ and the emission intensity of carbon monoxide $\mathrm{E}_{\mathrm{CO}}$, the Pearson r, Spearman R, Kruskal Gamma, and Kendall tau correlation coefficients, as well as the probability of rejection of the hypothesis regarding an absence of correlations in the examined sets

Rys. 4. Zależność korelacyjna natężenia emisji tlenków azotu $E_{N O \mathrm{x}}$ i natężenia emisji tlenku węgla $E_{C O}$; wspótczynniki korelacji Pearsona r, Spearmana R, Kruskala Gamma i Kendalla tau oraz prawdopodobieństwo nieodrzucenia hipotezy o braku korelacji dla badanych zbiorów

korelacyjne natężeń emisji zanieczyszczeń oraz współczynniki korelacji Pearsona r, Spearmana R, Kruskala Gamma i Kendalla tau, a także prawdopodobieństwo nieodrzucenia hipotezy o braku korelacji dla badanych zbiorów. 
carbon monoxide and hydrocarbons generating process in the exhaust and similar reduction properties of both of these substances against oxygen.

The correlation of the emission rates of nitrogen monoxide and carbon monoxide is also very strong, yet the correlation coefficients are negative, which could be interpreted as a result of significant differences in the way these compounds are generated in the engine as well as significant differences in chemical properties against oxygen in particular.
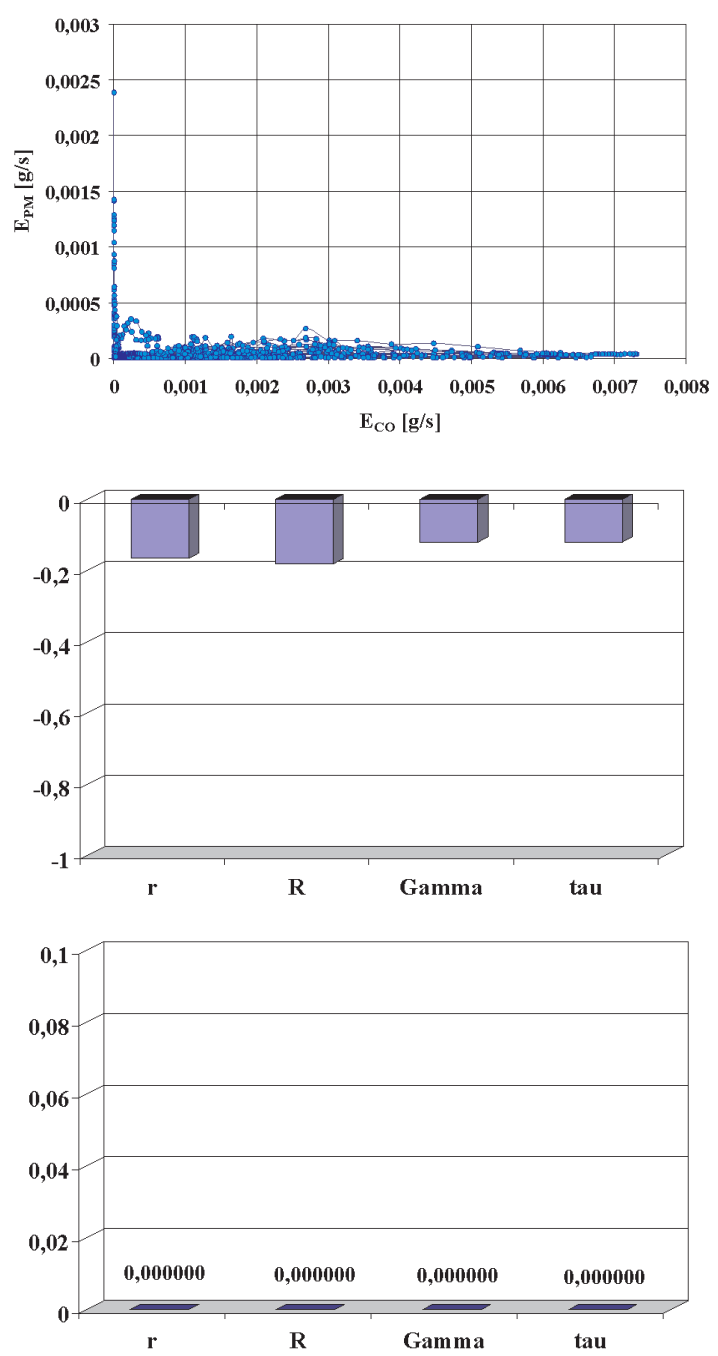

Fig. 5. Correlation dependence of the emission intensity of particulate matter $\mathrm{E}_{\mathrm{PM}}$ and the emission intensity of carbon monoxide $\mathrm{E}_{\mathrm{CO}}$, the Pearson r, Spearman R, Kruskal Gamma, and Kendall tau correlation coefficients, as well as the probability of rejection of the hypothesis regarding an absence of correlations in the examined sets

Rys. 5. Zależność korelacyjna natężenia emisji cząstek statych $E_{P M}$ i natężenia emisji tlenku węgla $E_{C O}$; współczynniki korelacji Pearsona $r$, Spearmana R, Kruskala Gamma i Kendalla tau oraz prawdopodobieństwo nieodrzucenia hipotezy o braku korelacji dla badanych zbiorów

Also, in the case of the correlation of the emission rates of particulate matter and carbon monoxide, negative correlation coefficients occurs (at strong correlation), which is difficult to interpret physically and chemically as opposed to the previous case.

The correlation of the emission rates of carbon dioxide and carbon monoxide is the weakest of all the analyzed
Korelacja natężeń emisji węglowodorów i tlenku węgla jest bardzo silna. Prawdopodobieństwo nieodrzucenia hipotezy o braku korelacji dla badanych zbiorów jest mniejsze niż $5 \cdot 10^{-7}$. Tak silna korelacja jest uzasadniona fizycznie i chemicznie podobnymi procesami generowania tlenku węgla i węglowodorów w spalinach oraz podobnymi redukcyjnymi właściwościami obydwu substancji względem tlenu.

Korelacja natężeń emisji tlenków azotu i tlenku węgla jest równieżbardzo silna,jednak współczynniki korelacji sąujemne,
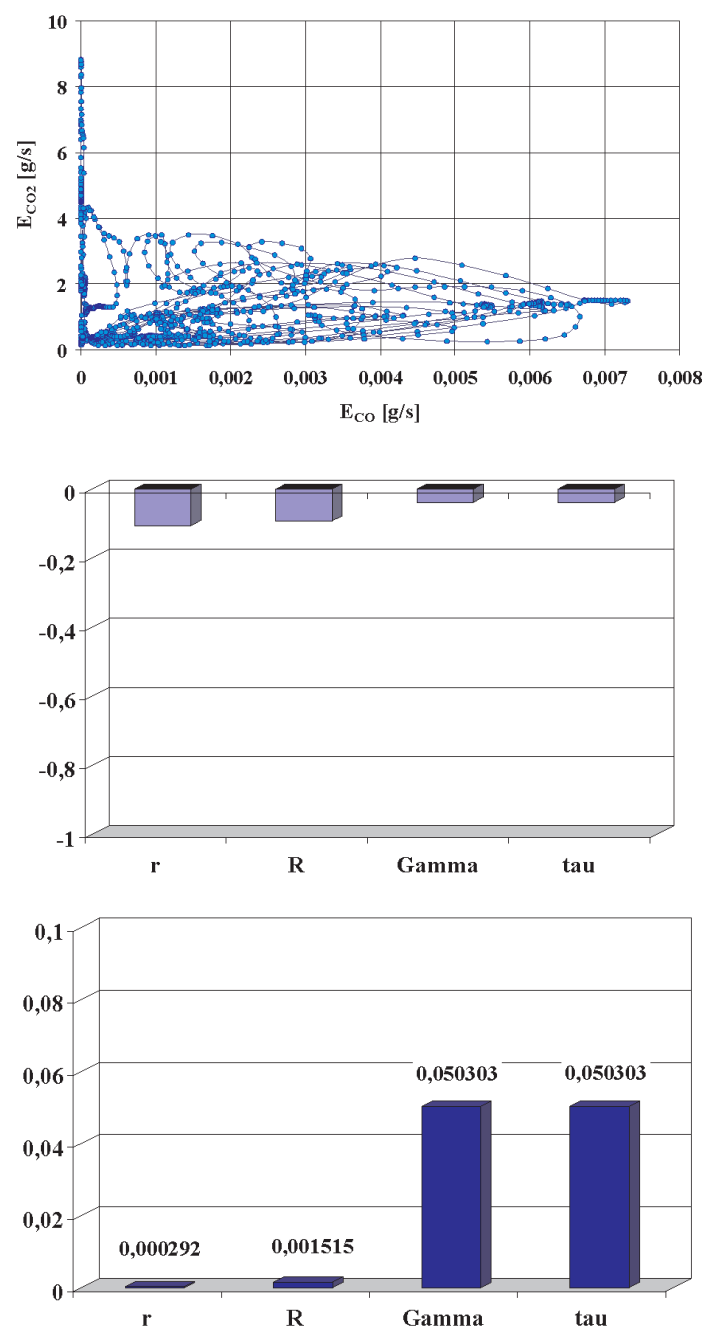

Fig. 6. Correlation dependence of the emission intensity of carbon dioxide $\mathrm{E}_{\mathrm{CO} 2}$ and the emission intensity of carbon monoxide $\mathrm{E}_{\mathrm{CO}}$, the Pearson $\mathrm{r}$, Spearman R, Kruskal Gamma, and Kendall tau correlation coefficients, as well as the probability of rejection of the hypothesis regarding an absence of correlations in the examined sets

Rys. 6. Zależność korelacyjna natężenia emisji dwutlenku węgla $E_{\mathrm{CO} 2} i$ natężenia emisji tlenku węgla $E_{C o}$; wspótczynniki korelacji Pearsona $r$, Spearmana R, Kruskala Gamma i Kendalla tau oraz prawdopodobieństwo nieodrzucenia hipotezy o braku korelacji dla badanych zbiorów

co można interpretować jako skutek znacznych różnic w sposobach powstawania tych związków w silniku oraz znaczących różnic właściwości chemicznych, w szczególności względem tlenu.

Także dla korelacji natężeń emisji cząstek stałych i tlenku węgla występują - przy silnej korelacji - ujemne współczynniki korelacji, co jest jednak - w odróżnieniu od 
sets. The probability of not rejecting of the hypothesis of a lack of correlation for the investigated sets exceeds $5 \%$ for the case of the Kruskal and Kendall theory. The correlation coefficients are negative as the reduction of the emission of carbon monoxide could be accompanied (at constant fuel consumption) by a growth of the emission of carbon dioxide, which results from the balance of carbon mass.
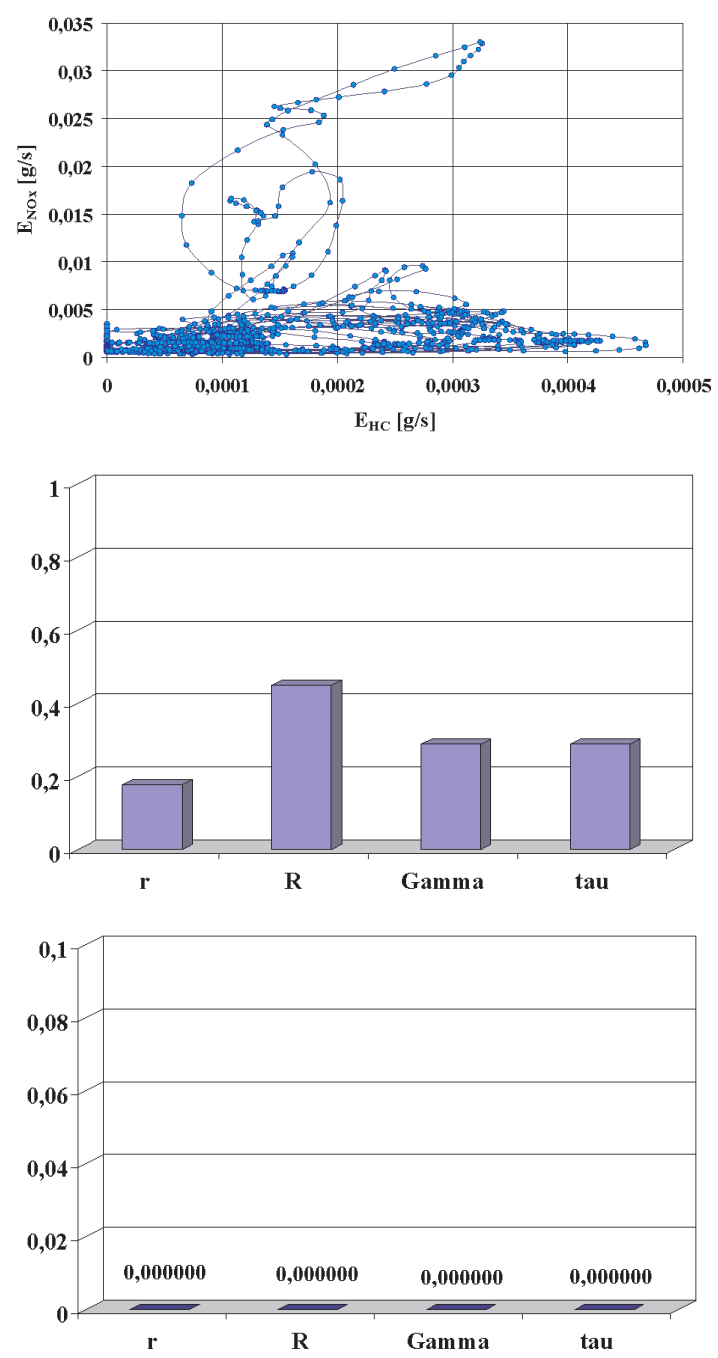

Fig. 7. Correlation dependence of the emission intensity of nitrogen oxides $\mathrm{E}_{\mathrm{NOx}}$ and the emission intensity of hydrocarbons $\mathrm{E}_{\mathrm{HC}}$, the Pearson $\mathrm{r}$, Spearman R, Kruskal Gamma, and Kendall tau correlation coefficients, as well as the probability of rejection of the hypothesis regarding an absence of correlations in the examined sets

Rys. 7. Zależność korelacyjna natężenia emisji tlenków azotu $E_{N O x}$ i natężenia emisji węglowodorów $E_{H C}$; wspótczynniki korelacji Pearsona $r$, Spearmana R, Kruskala Gamma i Kendalla tau oraz prawdopodobieństwo nieodrzucenia hipotezy o braku korelacji dla badanych zbiorów

The emissions of nitrogen oxides and hydrocarbons there bear a strong positive correlation. It is also the case for the emissions of particulate matter and hydrocarbons (Fig. 8).

For the emission rates of carbon dioxide and hydrocarbons there is a strong correlation. The correlation coefficients are positive as opposed to the coefficients of the correlation of the emission rates of carbon monoxide and carbon dioxide. Similar, positive correlation coefficients occur in the case of poprzedniego przypadku - wynikiem trudnym do interpretacji fizykochemicznej.

Korelacja natężeń emisji dwutlenku węgla i tlenku węgla jest najsłabsza spośród analizowanych zbiorów. Prawdopodobieństwo nieodrzucenia hipotezy o braku korelacji dla badanych zbiorów przekracza nawet $5 \% \mathrm{w}$ odniesieniu do teorii Kruskala i Kendalla. Współczynniki korelacji są
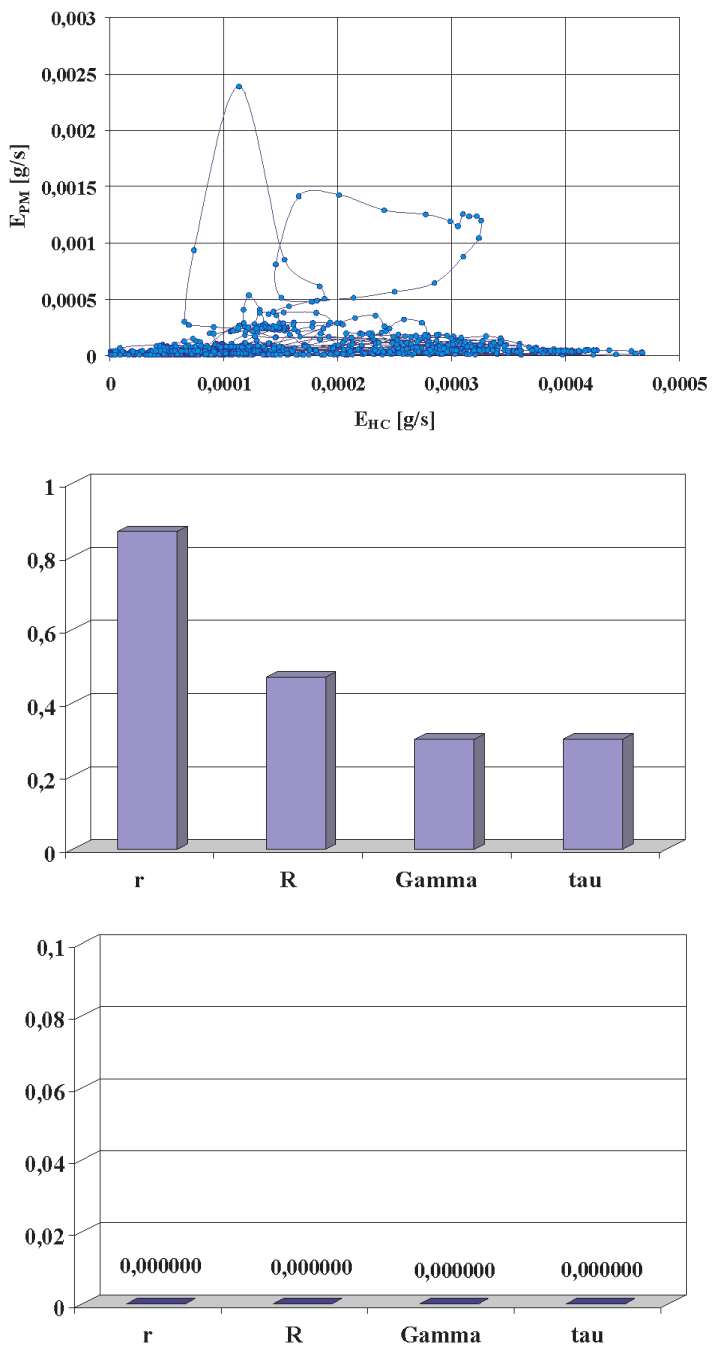

Fig. 8. Correlation dependence of the emission intensity of particulate matter $\mathrm{E}_{\mathrm{PM}}$ and the emission intensity of hydrocarbons $\mathrm{E}_{\mathrm{HC}}$, the Pearson $\mathrm{r}$, Spearman R, Kruskal Gamma, and Kendall tau correlation coefficients, as well as the probability of rejection of the hypothesis regarding an absence of correlations in the examined sets

Rys. 8. Zależność korelacyjna natężenia emisji cząstek statych $E_{P M}$ i natężenia emisji węglowodorów $E_{H C}$; wspótczynniki korelacji Pearsona $r$, Spearmana R, Kruskala Gamma i Kendalla tau oraz prawdopodobieństwo nieodrzucenia hipotezy o braku korelacji dla badanych zbiorów

ujemne, bowiem zmniejszaniu się emisji tlenku węgla przy stałym zużyciu paliwa może towarzyszyć zwiększanie się emisji dwutlenku węgla, co wynika z bilansu masy węgla.

Między natężeniami emisji tlenków azotu i węglowodorów zachodzi silna korelacja dodatnia. Podobnie jest w przypadku natężeń emisji cząstek stałych i węglowodorów (rys. 8).

Dla natężeń emisji dwutlenku węgla i węglowodorów istnieje silna korelacja. Współczynniki korelacji są dodatnie 
the emission rates of nitrogen oxides and particulate matter, nitrogen oxides and carbon dioxide and particulate matter and carbon dioxide.
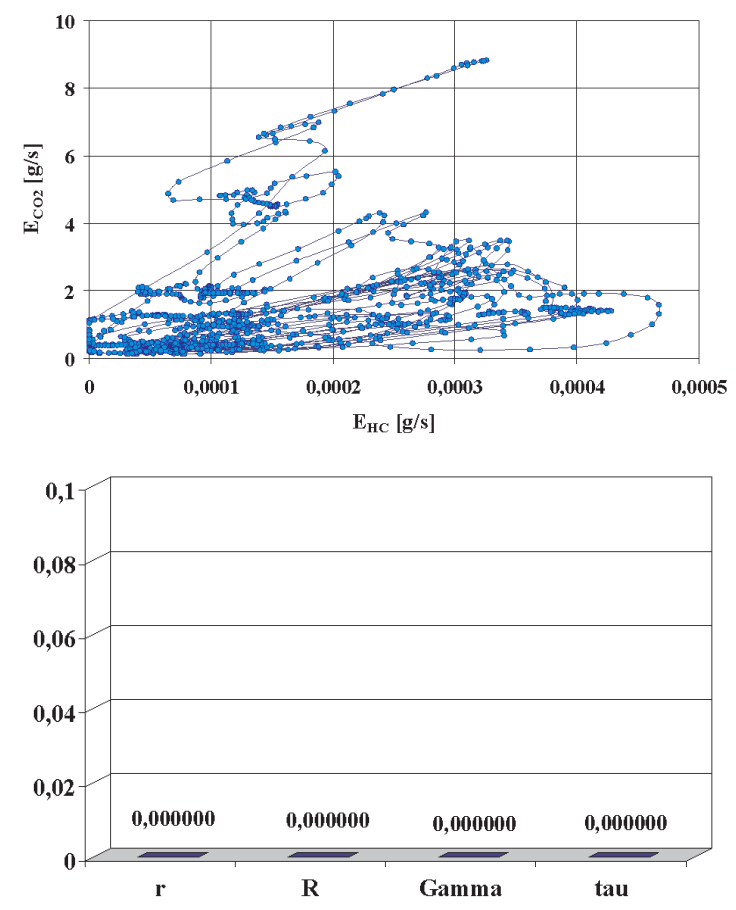

\section{Conclusions}

The following conclusions on the correlation of the pollutant emission intensity from self-ignition engines subject to motor vehicle test conditions pursuant to ECE R 83 rules may be formulated:

1. The pollutant emission intensity processes are strongly correlated with each other. The probability of nonrejection of the hypothesis of an absence of a correlation was equal to zero with an accuracy of at least six places after the decimal point, with the exception of the correlation between the carbon monoxide and carbon dioxide emission intensity processes for which the probability of non-rejection of the hypothesis of an absence of the correlation amounted to a maximum of approximately $5 \%$ (Gamma and tau correlation coefficients).

2. Noteworthy is the fact that the correlation coefficients for the carbon monoxide emission intensity and the emission intensity of other pollutants with the exception of hydrocarbons are not only smaller due to the absolute value, but even negative. The same is true in the case of the correlation analysis of the carbon monoxide emission intensity and the fuel flow intensity, which was not presented in this paper.

3. The result of correlation analysis of the nitrogen oxides and particulate matter emission intensity are puzzling: In line with all theories as examined in this paper, the correlation coefficients have positive values. Apart from this, the certainty of results is clear because the value of the correlation coefficients is close to one, and the probability of non-rejection of the hypothesis of an absence of cor- w przeciwieństwie do współczynników korelacji natężeń emisji dwutlenku węgla i tlenku węgla. Podobnie dodatnie współczynniki korelacji są w przypadku natężeń emisji tlenków azotu i cząstek stałych, tlenków azotu i dwutlenku węgla oraz cząstek stałych i dwutlenku węgla.

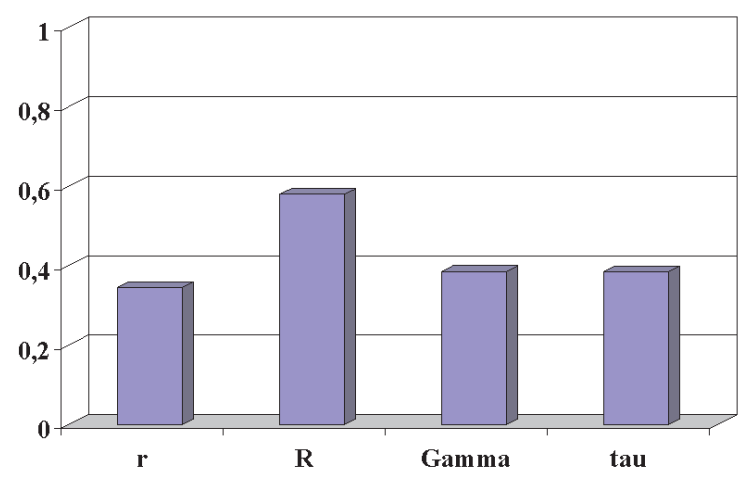

Fig. 9. Correlation dependence of the emission intensity of carbon dioxide $\mathrm{E}_{\mathrm{CO} 2}$ and the emission intensity of hydrocarbons $\mathrm{E}_{\mathrm{HC}}$, the Pearson $\mathrm{r}$, Spearman R, Kruskal Gamma, and Kendall tau correlation coefficients, as well as the probability of rejection of the hypothesis regarding an absence of correlations in the examined sets

Rys. 9. Zależność korelacyjna natężenia emisji dwutlenku węgla $E_{\mathrm{CO} 2}$ i natężenia emisji węglowodorów $E_{H C}$; współczynniki korelacji Pearsona $r$, Spearmana R, Kruskala Gamma i Kendalla tau oraz prawdopodobieństwo nieodrzucenia hipotezy o braku korelacji dla badanych zbiorów

\section{Wnioski}

Na podstawie przeprowadzonych badań można sformułować następujące wnioski na temat korelacji natężeń emisji zanieczyszczeń z silnika o zapłonie samoczynnym $\mathrm{w}$ warunkach testu samochodu zgodnie $\mathrm{z}$ regulaminem $\mathrm{nr}$ 83 EKG:

1. Przebiegi natężeń emisji zanieczyszczeń są ze sobą silnie skorelowane. Prawdopodobieństwo nieodrzucenia hipotezy o braku korelacji było równe zeru z dokładnością co najmniej do sześciu znaków po przecinku; wyjątkiem były badania korelacyjne między przebiegami natężeń emisji tlenku węgla i dwutlenku węgla, dla których prawdopodobieństwo nieodrzucenia hipotezy o braku korelacji było maksymalnie równe około 5\% (współczynniki korelacji Gamma i tau).

2. Jest znamienne, że współczynniki korelacji natężenia emisji tlenku węgla z natężeniami emisji innych zanieczyszczeń, z wyjątkiem węglowodorów, są nie tylko najmniejsze ze względu na wartość bezwzględną, ale i ujemne. Podobnie jest w przypadku nieprzedstawianej w niniejszej pracy analizy korelacyjnej natężeń emisji tlenku węgla z natężeniem przepływu paliwa zużywanego przez silnik.

3. Zastanawiający jest wynik analizy korelacji natężeń emisji tlenków azotu i cząstek stałych: współczynniki korelacji zgodnie ze wszystkimi teoriami, rozpatrywanymi w niniejszej pracy, mają wartości dodatnie, oprócz tego jednoznaczność wyników jest wyraźna, gdyż wartość współczynników korelacji jest zbliżona do jedności, a prawdopodobieństwa nieodrzucenia hipotezy o braku 
relation was equal to zero with an accuracy of at least six places after the decimal point. The result of these analyses is not in agreement with generally accepted observations regarding opposing sensitivities of the nitrogen oxides and particulate matter emissions to factors moulding those emissions. The formulation of general conclusions on the basis of correlation analysis results for the emission of nitrogen oxides and particulate matter as presented in this paper most certainly cannot be justified, as there is a need to significantly expand on the treatment of this topic.

The method applying correlation analysis of pollutant emission intensity subject to dynamic conditions turned out to be an effective tool in discovering the environmental properties of the combustion engine. This method may serve as a supplement to regulatory studies targeted at decreasing pollutant emissions under conditions corresponding to real combustion engine use [1].

The presented research results relate to homologation test operation conditions that may differ significantly from real combustion engine use conditions as applied to motor vehicles [1] and other uses [12]. In order to generalize the conclusions formulated in this paper as well as to broaden their scope, it is necessary to undertake a greatly expanded research programme encompassing various implementations of the same processes, various tests, and ultimately, for various objects. korelacji są równe zeru z dokładnością co najmniej do sześciu znaków po przecinku. Wynik tych analiz nie jest zgodny z ogólnie obowiązującymi spostrzeżeniami o przeciwstawnych wrażliwościach emisji tlenków azotu i cząstek stałych na czynniki kształtujące te emisje. Sformułowanie ogólnych wniosków na podstawie przedstawionych $\mathrm{w}$ niniejszej pracy wyników analizy korelacyjnej emisji tlenków azotu i cząstek stałych nie jest uprawnione, istnieje bowiem konieczność znacznie obszerniejszego potraktowania tego tematu.

Metoda badań korelacyjnych natężeń emisji zanieczyszczeń w warunkach dynamicznych okazała się skutecznym narzędziem poznawania właściwości ekologicznych silnika spalinowego. Metoda ta może stanowić uzupełnienie badań regulacyjnych, ukierunkowanych na zmniejszenie emisji zanieczyszczeń w warunkach odpowiadających rzeczywistemu użytkowaniu silników spalinowych [1].

Przedstawione wyniki badań dotyczą warunków pracy testu homologacyjnego, które mogą znacznie różnić się od rzeczywistych warunków użytkowania silników spalinowych o zastosowaniach zarówno samochodowych [1], jak i innych [12]; w celu uogólnienia wniosków, sformułowanych w niniejszej pracy, oraz rozszerzenia ich zakresu, niezbędna jest realizacja znacznie szerszego programu badań: dla różnych realizacji tych samych procesów, dla różnych testów i - wreszcie - dla różnych obiektów.

\section{Paper reviewed/Artykut recenzowany}

\section{Bibliography/Literatura}

[1] Chłopek Z.: Badania warunków pracy silnika spalinowego $\mathrm{w}$ czasie rzeczywistego użytkowania w autobusie miejskim. Archiwum Motoryzacji 2/2007.

[2] Chłopek Z.: Modelowanie procesów emisji spalin w warunkach eksploatacji trakcyjnej silników spalinowych. Prace Naukowe, seria Mechanika, z. 173. Oficyna Wydawnicza Politechniki Warszawskiej, Warszawa 1999.

[3] Chłopek Z., Darkowski A., Piaseczny L.: Influence of metaloorganic additive to the fuel on the pollution emission from the SI engine. Polish Journal of Environmental Studies. Vol. 14, No. 5 (2005), p. 559-567.

[4] Chłopek Z., Domański D.: Badania optymalizacyjne algorytmów sterowania silnika o zapłonie samoczynnym. Archiwum Motoryzacji 1/2007.

[5] Chłopek Z., Domański D.: Problemy optymalizacji sterowania silników spalinowych. Mechanika, z. 6-M/2004, Wydawnictwo Politechniki Krakowskiej, Kraków 2004.

[6] Chłopek Z., Piaseczny L.: Analiza korelacyjna właściwości silnika spalinowego w statycznych warunkach pracy. Mechanika, z. 6-M/2004, Wydawnictwo Politechniki Krakowskiej, Kraków 2004.

Mr. Zdzisław Chłopek, DSc., DEng. - Professor in the Automotive Industry Institute in Warsaw.

Dr hab. inż. Zdzislaw Chtopek - profesor w Przemystowym Instytucie Motoryzacji w Warszawie.

e-mail:moriarty@o2.pl

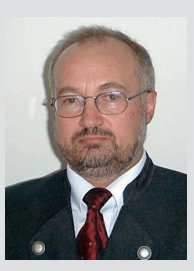

[7] Chłopek Z., Piaseczny L.: Badania statystycznych właściwości silnika spalinowego w statycznych warunkach pracy. Zeszyty Naukowe Akademii Marynarki Wojennej, rok XLV, nr 1(156), Gdynia 2004

[8] Chłopek Z., Piaseczny L.: Statistical investigations of fast changeable processes in ship piston combustion engines. Polish Maritime Research No. 2(44), 2005, Vol. 12.

[9] Kendall M.G.: A New measure of rank correlation. 1938. Biometrika, 30, p. 81-89.

[10] Kendall M.G.: Rank correlation methods. Wyd. 1, Charles Griffin \& Company Limited, Londyn 1948.

[11] Kruskal H., Wallis W.A.: Use of ranks in one-criterion variance analysis. Journal of the American Statistical Association 47 (260). 1952, p. 583-621.

[12] Marecka-Chłopek E., Chłopek Z.: Synteza testów statycznych do badania silników spalinowych o zastosowaniach innych niż samochodowe ze względu na emisję zanieczyszczeń i zużycie paliwa. Przegląd Mechaniczny 9/2007.

[13] Pearson K.: On the theory of contingency and its relation to association and normal correlation. Drapers' Company Research Memoirs. Biometric Ser. I, 1904.

[14] Savitzky A., Golay M.J.E.: Smoothing and differentiation of data by simplified least squares procedures. Analytical Chemistry, 1964, 36, p. 1627-1639.

[15] Spearman Ch.: The proof and measurement of association between two things. Americal Journal of Psychology. 15 (1904), p. $72-101$.

[16] Wasserman L.: All of nonparametric statistics. Springer 2007. 